\title{
Chasing Housing Prices?
}

\author{
Allen Atkins, Northern Arizona University, USA \\ Kevin C.H. Chiang, University of Vermont, USA \\ Ming-Long Lee, National Dong Hwa University, Taiwan
}

\begin{abstract}
If a person or organization is planning to buy real estate in the future but is unable or unwilling to buy it now, how can they best "hedge" this purchase? In what class of asset should they invest their money until they are ready to purchase the real estate? This paper uses Monte Carlo simulation and bootstrap techniques to investigate the effectiveness of using traditional asset classes in managing the long-term risks associated with the future purchase of real estate. We find that the best "purchase early" hedge for both residential and commercial real estate is small value stocks. Small value stocks would be the most likely to provide returns at least as good as real estate and they would be least likely to suffer losses relative to real estate. The effectiveness of the hedge increases the longer the time horizon of the investor. Large value stocks and equity REIT's are also quite good but not as good as small value stocks. Other asset classes are not nearly as effective. The least effective asset class is T-Bills.
\end{abstract}

Keywords: Housing Prices; REIT; Risk Management

\section{INTRODUCTION}

$\mathrm{n}$ some cases a person or institution may be planning on purchasing real estate, but for some reason they are not yet ready or able to actually buy. They may have some funds set aside for the purchase but they are not planning on actually making the purchase for several more years. What can they do with their funds between now and when they hope to buy to have the greatest chance of enhancing their ability to purchase? What asset classes tend to perform at least as well as real estate and have a low chance of losing relative to real estate over the planning horizon?

The real estate literature has addressed similar, but not identical issues. There is a wide body of research comparing real estate returns to other asset classes (Berg, Gu, and Lien (2007), Gyourko (1992), Kuhle (1987), Myer, Neil and Webb (1987), Quan (1999), and Webb (1982) among others). Another line of research considers whether and what portion of a person's portfolio should be invested in real estate (Cocco (2004), Chiang and Lee (2007), and Wilson (1996) among others). Also, several papers discuss real estate as a hedge for other investments (Jacobus (2004), and Frost (1995) among others). The purpose of this paper is related to these topics but somewhat different. We try to identify the best classes of assets that will allow an investor to prepare for a future purchase of real estate.

The time horizon for the future purchase of real estate affects the tools available to manage this risk. A tool for managing some of the short term risks has been launched. In April of 2006, The Chicago Mercantile Exchange (CME) began to offer futures and options contracts on housing prices. These contracts are standardized, maturityspecific instruments based on the Standard \& Poor/Case-Shiller Home Price Indices. They offer investors: (1) a lowcost exposure to real estate prices, (2) opportunities for hedging real estate prices, and (3) a way to make trading real estate a liquid, short-term investment. By trading on these indices, investors who want to manage their exposures to residential properties are able to speculate on a rise or drop in the housing market without having to buy or sell bricks and mortar.

Long-term risk management strategies may not be possible or effective using these new CME instruments because their maturities are no longer than one year. Traditional asset classes, however, could be useful in managing some of the long-term investment risk in the real estate industry. The purpose of this study is to 
investigate the effectiveness of using traditional asset classes in managing the long-term risks associated with the future purchase of real estate.

Several scenarios show how this knowledge could be useful. First, the city of Fairbanks acquired and received federal funding in the amount of $\$ 100$ million for developing an "affordable" housing subdivision. This project is in the process of obtaining approval on its environmental impact from the Department of Interior. This approval is not expected to be finalized for three years. The city of Fairbanks is, therefore, facing the possibility of greatly increased developing costs over the next three years. What type of assets could they invest in during the next three years to hedge against the possible increasing cost of real estate? It could be useful for them to identify an asset class that will have a good chance of performing at least as well as real estate and will have a very low chance of losing relative to real estate.

Alternatively, consider John Smith who is currently renting an apartment. He wants to buy a 3-bedroom house and the current price for a 3-bedroom house in the neighborhood he likes is about $\$ 500,000$. A low downpayment of $5 \%$ will require $\$ 25,000$, but he now has only $\$ 10,000$. The only way for him to acquire the remaining $\$ 15,000$ is to save from his salary which may take several years. John is worried about the purchasing power of his current $\$ 10,000$ in the future. He wants to invest the $\$ 10,000$ in securities that tend to have returns that are no less than the housing price increases during upswings and at the same time typically have losses no more than real estate declines during downswings. Should John invest the $\$ 10,000$ in stocks, bonds, T-bills, or real estate investment trusts (REITs)? Our results show that small value U. S. stocks are best at fulfilling this need followed by large value stocks and equity REITs. T-Bills are the least effective.

We believe that our study is relevant to real estate investors and practitioners Over the past decade real estate prices have been very volatile. Large increases in real estate prices have been followed by large decreases. Over the long term has real estate outperformed most other asset classes? Certainly many home owners have accumulated wealth in their homes. The reason for some of this, however, is that people usually purchase their homes using a large amount of leverage and they hold onto their homes for relatively long periods of time. If people use an equal amount of leverage and a similar holding period when investing in other assets how well would they have done? We show evidence that real estate returns, in and of themselves, are actually no better than most other investment classes. This is true even in time of increasing real estate prices. When real estate is compared to other assets on an equal basis, most other asset classes actually outperform real estate.

\section{THE DATA}

The data are collected from January 1972 through December 2005. The abbreviations used in the exhibits are shown in parentheses. The monthly residential housing returns are based on median sale prices of U.S. new houses and are collected from U.S. Census Bureau (Residential). Although not the main focus of the paper, we also consider commercial real estate. The monthly commercial real estate returns are based on the Russell-NCREIF Commercial Property Index (Commercial). ${ }^{1}$ The following 10 popular asset classes are used in this study as comparison assets:

1. U.S. large value stock portfolio (Large Value),

2. U.S. large growth stock portfolio (Large Growth),

3. U.S. small value stock portfolio (Small Value),

4. U.S. small growth stock portfolio (Small Growth),

5. Morgan Stanley Capital International (MSCI) Europe, Australia, and Far East index (EAFE),

6. U.S. 3-month T-bills (T-Bills),

7. U.S. intermediate-term T-bonds (I-T T-Bonds),

8. U.S. long-term T-bonds (L-T T-Bonds),

9. National Association of Real Estate Investment Trusts (NAREIT) Equity REIT Index (EREITs)

10. NAREIT Mortgage REIT Index (MREITs).

\footnotetext{
${ }^{1}$ It is well known that appraisal-based index is smoothed. While the relatively time-stable returns are problematic to gauge the true return for each time period, the smoothing problem for measuring the return over a long period is moderate for a study like ours.
} 
The return series for the first four asset classes are provided by Kenneth French. The EAFE returns are retrieved from MSCI's website. The return series on asset classes 6, 7, and 8 are collected from the 2006 Stocks, Bonds, Bills, and Inflation (SBBI) yearbook. The two REIT return series are retrieved from NAREIT's website.

Exhibit 1 reports summary statistics for the residential and commercial real estate and the 10 comparison asset classes. Panel A reports the mean and standard deviation of each series. The largest return was for small value stocks and largest standard deviation was for small growth stocks. The smallest return and standard deviation was for T-Bills. Panel B shows the correlation coefficients between the returns on residential real estate and the returns on the 10 comparison asset classes. All of the correlations are quite low and range from -0.060 for large value stocks to +0.038 for T-Bills. Panel $\mathrm{C}$ shows the correlation coefficients between the returns on commercial real estate and the returns on the 10 comparison asset classes. These correlations are somewhat larger and range from 0.127 for Intermediate term T- Bonds to +0.331 for T-Bills.

\section{STATISTICAL METHODS}

This study consists of two sets of analyses, Monte Carlo experiments and bootstrap tests. First, Monte Carlo experiments are performed to demonstrate historical returns of traditional assets relative to real estate within the sample period of January 1972-December 2005. The results for residential real estate are shown in exhibit 2 and for commercial real estate in exhibit 4. Specifically, we randomly generate a large number of Monte Carlo realizations, drawn with replacement; each random realization is a consecutive block of returns of 1 to 10 years in length. Each random realization yields one measure of relative loss:

Relative loss = $\mid$ Min (0, end-of-period value of $\$ 1$ invested in alternative securities - end-ofperiod of $\$ 1$ invested in real estate)

Relative loss measures the loss of investing in alternative asset classes relative to investing in real properties. A "perfect" hedge will have a zero relative loss.

Exhibit 1

Returns on Various Asset Classes from 1972-2005

\begin{tabular}{|c|c|c|c|c|c|}
\hline \multicolumn{6}{|c|}{ Panel A: Mean Returns (Standard Deviation) } \\
\hline Residential & Commercial & Large Value & Large Growth & Small Value & Small Growth \\
\hline $\begin{array}{l}7.27 \\
(13.28)\end{array}$ & $\begin{array}{l}9.60 \\
(3.41)\end{array}$ & $\begin{array}{l}14.55 \\
(15.34)\end{array}$ & $\begin{array}{l}11.11 \\
(17.05)\end{array}$ & $\begin{array}{l}18.74 \\
(18.38)\end{array}$ & $\begin{array}{l}10.52 \\
(24.60)\end{array}$ \\
\hline $\begin{array}{l}\text { EAFE } \\
9.50 \\
(16.78)\end{array}$ & $\begin{array}{l}\frac{\text { T-Bills }}{5.90} \\
(0.85)\end{array}$ & $\begin{array}{l}\frac{\text { I-T T-Bonds }}{7.92} \\
(5.72)\end{array}$ & $\begin{array}{l}\frac{\text { L-T T-Bonds }}{9.08} \\
(10.42)\end{array}$ & $\begin{array}{l}\text { EREITs } \\
13.59 \\
(13.75)\end{array}$ & $\begin{array}{l}\text { MREITs } \\
8.61 \\
(20.31)\end{array}$ \\
\hline \multicolumn{6}{|c|}{ Panel B: Correlation Coefficients of Other Assets with Residential Properties } \\
\hline$\frac{\text { Residential }}{1.0000}$ & $\frac{\text { Commercial }}{\text { NA }}$ & $\frac{\text { Large Value }}{-0.0604}$ & $\begin{array}{l}\text { Large Growth } \\
-0.0469\end{array}$ & $\frac{\text { Small Value }}{-0.0417}$ & $\frac{\text { Small Growth }}{-0.0443}$ \\
\hline$\frac{\text { EAFE }}{0.0206}$ & $\frac{\text { T-Bills }}{-0.0238}$ & $\frac{\text { I-T T-Bonds }}{0.0069}$ & $\frac{\text { L-T T-Bonds }}{0.0379}$ & $\frac{\text { EREITs }}{-0.0501}$ & $\frac{\text { MREITs }}{-0.0471}$ \\
\hline \multicolumn{6}{|c|}{ Panel C: Correlation Coefficients of Other Assets with Commercial Properties } \\
\hline$\frac{\text { Residential }}{\text { NA }}$ & $\frac{\text { Commercial }}{1.00}$ & $\frac{\text { Large Value }}{-0.0389}$ & $\frac{\text { Large Growth }}{-0.0571}$ & $\frac{\text { Small Value }}{-0.0703}$ & $\frac{\text { Small Growth }}{-0.0517}$ \\
\hline$\underline{\text { EAFE }}$ & $\frac{\text { T-Bills }}{0.3313}$ & $\frac{\text { I-T T-Bonds }}{-0.1274}$ & $\begin{array}{l}\text { L-T T-Bonds } \\
-0.1221\end{array}$ & $\frac{\text { EREITs }}{0.0188}$ & $\frac{\text { MREITs }}{-0.1176}$ \\
\hline
\end{tabular}


For example, given the principle of $\$ 1.00$, if an alternative investment had an end of period value of $\$ 2.00$ and real estate had an end of period value of $\$ 1.50$, the difference in returns would be $+50 \%$. In this case the relative loss would be zero (the relative loss formula above would yield a zero), because the alternative investment outperformed real estate. In an opposite situation, if the alternative investment had an end of period value of $\$ 1.8$ and real estate had a value of $\$ 2.4$, the relative loss would be $-60 \%$. This would indicate that the alternative investment performed worse than real estate and would not be a very good hedge.

Overall, these experiments provide descriptive statistics about the historical usefulness of traditional securities to carry out a "purchase-early" hedge strategy. ${ }^{2}$ That is, the average size of relative losses from random realizations can be used to measure hedging effectiveness and downside risk. The use of average relative loss has a long history in the risk literature, and is also called the lower partial moment of order 1 (Bawa, 1975). In effect, this is a way to realize "real-estate type" returns, when it is not feasible to actually buy real estate.

The second set of analyses uses the bootstrap technique and allows for statistical inferences. The results for residential real estate are shown in exhibit 3 and for commercial real estate in exhibit 5. Our null hypothesis is that the end-of period value of $\$ 1$ invested in residential properties is greater than the end-of-period value of $\$ 1$ invested in alternative securities. A rejection of the null hypothesis implies that alternative securities are likely to be providing future returns at least as good as real estate and therefore provide a type of "purchase-early" hedge. Of course, the usual underlying assumption is that the January 1972-December 2005 returns are a random sample of the population. This study uses the bootstrap method to infer the sampling properties of the population because this method does not require any parametric assumption on the statistic.

Following Efron (1979), the January 1972-December 2005 returns are bootstrapped to form bootstrap samples of size $T$, where $T$ ranges from 12 to 120 months. Because of the existence of time dependence in the data, block bootstrapping is used. The block length used in the study is 6 months, which is consistent with the optimal asymptotic block length specified in Hall, Horowitz, and Jing (1995). That is, a bootstrap sample of size $T$ consists of $T / 6$ blocks of returns. This experiment is repeated 10,000 times for each test. These 10,000 realizations are used to construct the bootstrap distribution and to estimate the sampling distribution. Once the sampling distribution is obtained, statistical inferences can be made in the usual way. The numeric values in exhibit 3 and 5 are $p$-values that indicate whether real estate will have a higher return than other asset classes. Small $p$-values, for example under 10 , indicate that the null hypothesis is rejected at the $10 \%$ significance level. This would show that the alternative investment class should significantly outperform real estate in the future.

\section{EMPIRICAL RESULTS}

Exhibit 2 reports Monte Carlo experiment results. The probability of being better off investing in residential properties relative to any alternative asset class is less than 50\%. This is true for investment horizons of one to ten years. The only exception is investing in T-Bills for just one year. In other words, if an investor has no superior information and uses the same financial leverage on all investments, the investor would have a better chance of a high return by investing in virtually any alternative asset classes during the January 1972-December 2005 period.

The results also show that as the investment horizon lengthens alternative asset classes become better "purchase-early" hedges. For example, the probabilities of being better off by investing in residential properties relative to large value stocks, for the investment horizons of one to ten years, are $28.37 \%, 21.24 \%, 18.58 \%, 11.86 \%$, $8.54 \%, 8.14 \%, 2.78 \%, 0.64 \%, 0.00 \%$, and $0.00 \%$, respectively. The associated average relative losses are $3.68 \%$, $1.95 \%, 1.12 \%, 0.49 \%, 0.29 \%, 0.17 \%, 0.00 \%, 0.00 \%, 0.00 \%$, and $0.00 \%$ per year, respectively. Large value stocks are perfect hedges once the investment horizon is nine years or longer.

It is not surprising that equity REITs are also good "purchase-early" hedges because their returns are fundamentally derived from their underlying real properties. The probabilities of being better off by investing in

\footnotetext{
${ }^{2}$ Luenberg (1998) discusses a type of hedge which is like "purchasing early" something that must ultimately be purchased. This is what we call the "purchase-early" hedge.
} 
residential properties relative to equity REITs, for the investment horizons of one to ten years, are $28.61 \%, 23.88 \%$, $20.72 \%, 12.45 \%, 12.81 \%, 5.40 \%, 3.53 \%, 1.82 \%, 0.00 \%$, and $0.00 \%$, respectively. The associated average relative losses are $3.73 \%, 2.47 \%, 1.63 \%, 0.86 \%, 0.52 \%, 0.37 \%, 0.18 \%, 0.00 \%, 0.00 \%$, and $0.00 \%$ per year, respectively. In contrast, International stocks and fixed income securities, including T-bills, intermediate-term government bonds, long-term government bonds, and mortgage REITs, are less effective in chasing housing prices.

Exhibit 2

Monte Carlo Experiments for Residential Properties

\begin{tabular}{lcccccccccc}
\hline $\begin{array}{c}\text { Horizon } \\
\text { (Year) }\end{array}$ & $\mathbf{1}$ & $\mathbf{2}$ & $\mathbf{3}$ & $\mathbf{4}$ & $\mathbf{5}$ & $\mathbf{6}$ & $\mathbf{7}$ & $\mathbf{8}$ & $\mathbf{9}$ & $\mathbf{1 0}$ \\
\hline Large Value & 28.36 & 21.24 & 18.58 & 11.86 & 8.54 & 8.14 & 2.78 & 0.64 & 0.00 & 0.00 \\
& $(3.68)$ & $(1.95)$ & $(1.12)$ & $(0.49)$ & $(0.29)$ & $(0.17)$ & $(0.00)$ & $(0.00)$ & $(0.00)$ & $(0.00)$ \\
Large Growth & 38.53 & 38.30 & 31.80 & 27.86 & 27.25 & 24.09 & 16.73 & 11.68 & 9.78 & 10.38 \\
& $(6.12)$ & $(4.50)$ & $(3.53)$ & $(2.81)$ & $(2.40)$ & $(2.05)$ & $(1.40)$ & $(1.05)$ & $(0.89)$ & $(0.74)$ \\
Small Value & 23.58 & 17.07 & 6.79 & 8.01 & 3.70 & 1.21 & 0.60 & 0.00 & 0.00 & 0.00 \\
& $(3.75)$ & $(1.68)$ & $(0.73)$ & $(0.43)$ & $(0.12)$ & $(0.00)$ & $(0.00)$ & $(0.00)$ & $(0.00)$ & $(0.00)$ \\
Small Growth & 39.55 & 31.69 & 35.32 & 37.01 & 33.05 & 30.66 & 26.40 & 25.08 & 19.71 & 14.10 \\
& $(8.61)$ & $(4.83)$ & $(3.43)$ & $(2.84)$ & $(2.39)$ & $(1.73)$ & $(1.40)$ & $(0.82)$ & $(0.45)$ & $(0.38)$ \\
EAFE & 46.54 & 42.30 & 41.51 & 43.67 & 38.88 & 36.96 & 33.64 & 32.50 & 29.68 & 28.37 \\
& $(6.22)$ & $(4.37)$ & $(3.65)$ & $(3.15)$ & $(2.60)$ & $(2.09)$ & $(1.88)$ & $(1.67)$ & $(1.54)$ & $(1.36)$ \\
T-Bills & 51.89 & 48.96 & 43.81 & 41.55 & 41.04 & 33.49 & 29.42 & 22.31 & 18.00 & 16.46 \\
& $(2.91)$ & $(2.39)$ & $(2.01)$ & $(1.75)$ & $(1.54)$ & $(1.22)$ & $(0.99)$ & $(0.63)$ & $(0.43)$ & $(0.29)$ \\
I-T T-Bonds & 43.74 & 40.93 & 34.40 & 26.81 & 20.85 & 19.58 & 14.97 & 13.03 & 10.78 & 8.57 \\
& $(3.12)$ & $(2.09)$ & $(1.67)$ & $(1.40)$ & $(1.25)$ & $(1.19)$ & $(1.01)$ & $(0.77)$ & $(0.60)$ & $(0.30)$ \\
L-T T-Bonds & 43.22 & 36.21 & 29.91 & 26.75 & 23.86 & 23.06 & 21.81 & 21.25 & 17.35 & 14.46 \\
& $(4.28)$ & $(2.72)$ & $(2.11)$ & $(1.96)$ & $(1.84)$ & $(1.78)$ & $(1.71)$ & $(1.50)$ & $(1.17)$ & $(0.83)$ \\
EREIT & 28.61 & 23.88 & 20.72 & 12.45 & 12.81 & 5.40 & 3.53 & 1.82 & 0.00 & 0.00 \\
& $(3.73)$ & $(2.47)$ & $(1.63)$ & $(0.86)$ & $(0.52)$ & $(0.37)$ & $(0.18)$ & $(0.00)$ & $(0.00)$ & $(0.00)$ \\
MREIT & 44.34 & 45.56 & 43.33 & 39.22 & 45.43 & 36.72 & 37.90 & 38.75 & 39.37 & 34.31 \\
& $(8.86)$ & $(6.73)$ & $(5.05)$ & $(4.04)$ & $(3.41)$ & $(3.13)$ & $(2.87)$ & $(2.62)$ & $(2.24)$ & $(1.57)$ \\
\hline Notes: The top line
\end{tabular}

Notes: The top line in each row shows the probability that Residential Real Estate will have a higher return than other assets over the horizon period. The bottom line shows the average relative loss in returns relative to other assets.

It may seem somewhat surprising that small value stocks are the best "purchase-early" hedges for residential properties. The probabilities of being better off from investing in residential properties relative to small value stocks, for the investment horizons of one to ten years, are $23.58 \%, 17.07 \%, 6.79 \%, 8.01 \%, 3.70 \%, 1.21 \%$, $0,60 \%, 0.00 \%, 0.00 \%$, and $0.00 \%$, respectively. The associated average relative losses are $3.75 \%, 1.68 \%, 0.73 \%$, $0.43 \%, 0.12 \%, 0.00 \%, 0.00 \%, 0.00 \%, 0.00 \%$, and $0.00 \%$ per year, respectively. Small value stocks are perfect hedges once the investment horizon is eight years or longer. There are at least two reasons why small value stocks perform the best: (1) small value stocks have the highest mean return among all asset classes examined, and (2) small value returns and real estate returns seem to be somewhat related. Chiang and Lee (2002) show that the predominant style of equity REITs is the small value style; that is, equity REIT returns are best explained by small value stock returns.

Exhibit 3 reports the bootstrap $p$ values for testing the null hypothesis that the end-of period value of $\$ 1$ invested in residential properties is greater than the end-of-period value of $\$ 1$ invested in alternative securities. The results indicate that after taking into account the random nature of the sample, there is a high degree of statistical confidence that small value stocks will provide future returns at least as good as real estate and therefore provide an effective type of "purchase-early" hedge. The null hypothesis is rejected at the 10\% (5\%) level for investment horizons seven (nine) years and beyond. In addition, large value stocks and equity REITs exhibit desirable properties; their $p$ values are also rather small. The least effective asset class is T-Bills.

What if someone wants to have a similar type hedge for commercial properties? Are there any asset classes that are effective as "purchase-early" hedges for commercial property? We repeat our analyses by replacing returns on residential property with the returns commercial property. Because the returns on commercial real estate are 
available only in quarterly frequency, this analysis compounds all monthly return series into quarterly return series. In addition, the test period is from 1978 to 2005 because the Russell-NCREIF data set begins in 1978.

Exhibit 4 reports the Monte Carlo results for commercial properties. Again the results indicate that small value stocks provide the best "purchase-early" hedge. The probability of commercial real estate outperforming small value stocks is zero for seven years and beyond. Equity REIT's and large value stocks again perform well and the other asset classes are less effective.

Exhibit 3

A Bootstrap Technique for Residential Properties

\begin{tabular}{|c|c|c|c|c|c|c|c|c|c|c|}
\hline $\begin{array}{c}\text { Horizon } \\
\text { (Year) }\end{array}$ & 1 & 2 & 3 & 4 & 5 & 6 & 7 & 8 & 9 & 10 \\
\hline Large Value & 30.01 & 25.16 & 21.42 & 19.37 & 16.05 & 14.62 & 12.44 & 10.71 & $9.60 *$ & $8.71 *$ \\
\hline Large Growth & 41.93 & 39.13 & 37.07 & 35.89 & 34.03 & 32.55 & 31.08 & 30.78 & 29.64 & 28.98 \\
\hline Small Value & 28.19 & 21.92 & 17.84 & 14.77 & 12.36 & 10.32 & $8.71 *$ & $6.94 *$ & $6.02 *$ & $4.91 * *$ \\
\hline Small Growth & 47.13 & 46.73 & 47.35 & 46.93 & 46.13 & 47.08 & 47.24 & 45.64 & 45.51 & 44.86 \\
\hline EAFE & 46.64 & 45.78 & 45.54 & 44.26 & 43.74 & 42.97 & 41.57 & 41.36 & 41.11 & 41.45 \\
\hline T-Bills & 52.75 & 54.03 & 55.12 & 54.88 & 55.84 & 55.82 & 55.64 & 57.18 & 58.51 & 57.20 \\
\hline I-T T-Bonds & 44.50 & 41.37 & 38.33 & 37.64 & 35.48 & 33.95 & 33.43 & 32.77 & 31.60 & 30.26 \\
\hline L-T T-Bonds & 42.58 & 39.42 & 37.90 & 34.89 & 33.64 & 32.31 & 31.38 & 29.42 & 28.63 & 28.15 \\
\hline EREIT & 31.77 & 26.67 & 22.78 & 20.40 & 17.68 & 15.47 & 13.78 & 11.85 & 10.83 & $9.67 *$ \\
\hline MREIT & 47.39 & 46.81 & 46.36 & 46.45 & 45.89 & 46.89 & 46.16 & 46.72 & 45.49 & 45.43 \\
\hline
\end{tabular}

Exhibit 4

Monte Carlo Experiments for Commercial Properties

\begin{tabular}{lccccccccccc}
\hline $\begin{array}{c}\text { Horizon } \\
\text { (Year) }\end{array}$ & $\mathbf{1}$ & $\mathbf{2}$ & $\mathbf{3}$ & $\mathbf{4}$ & $\mathbf{5}$ & $\mathbf{6}$ & $\mathbf{7}$ & $\mathbf{8}$ & $\mathbf{9}$ & $\mathbf{1 0}$ \\
\hline Large Value & 36.47 & 30.85 & 29.33 & 23.89 & 14.48 & 15.05 & 15.46 & 14.48 & 13.48 & 7.19 \\
& $(4.06)$ & $(2.12)$ & $(1.99)$ & $(1.75)$ & $(1.21)$ & $(1.21)$ & $(0.98)$ & $(0.55)$ & $(0.38)$ & $(0.13)$ \\
Large Growth & 39.41 & 35.37 & 29.29 & 28.76 & 29.25 & 25.38 & 21.28 & 18.26 & 10.59 & 9.42 \\
& $(6.35)$ & $(4.07)$ & $(3.41)$ & $(3.27)$ & $(2.54)$ & $(1.99)$ & $(1.49)$ & $(0.77)$ & $(0.38)$ & $(0.12)$ \\
Small Value & 29.64 & 23.92 & 14.33 & 8.25 & 7.51 & 1.15 & 1.12 & 0.00 & 0.00 & 0.00 \\
& $(3.73)$ & $(1.29)$ & $(0.56)$ & $(0.30)$ & $(0.27)$ & $(0.00)$ & $(0.00)$ & $(0.00)$ & $(0.00)$ & $(0.00)$ \\
Small Growth & 47.06 & 41.92 & 51.60 & 55.78 & 53.18 & 51.07 & 44.48 & 45.14 & 43.87 & 43.70 \\
& $(9.20)$ & $(5.18)$ & $(4.79)$ & $(4.72)$ & $(4.41)$ & $(3.93)$ & $(3.89)$ & $(3.79)$ & $(3.41)$ & $(2.86)$ \\
EAFE & 52.18 & 58.76 & 63.91 & 61.28 & 53.13 & 45.04 & 36.67 & 32.22 & 35.00 & 41.22 \\
& $(7.81)$ & $(6.21)$ & $(6.31)$ & $(6.21)$ & $(5.60)$ & $(4.67)$ & $(4.18)$ & $(3.41)$ & $(3.21)$ & $(3.06)$ \\
T-Bills & 80.77 & 84.14 & 79.23 & 75.91 & 73.51 & 71.51 & 69.64 & 66.11 & 65.58 & 61.54 \\
& $(4.43)$ & $(4.42)$ & $(4.45)$ & $(4.54)$ & $(4.69)$ & $(4.88)$ & $(4.88)$ & $(4.75)$ & $(4.47)$ & $(4.03)$ \\
I-T T-Bonds & 56.73 & 52.10 & 50.61 & 48.54 & 46.18 & 42.87 & 42.68 & 38.75 & 38.34 & 34.25 \\
& $(4.76)$ & $(3.65)$ & $(3.08)$ & $(2.79)$ & $(2.70)$ & $(2.70)$ & $(2.55)$ & $(2.25)$ & $(2.06)$ & $(1.87)$ \\
L-T T-Bonds & 51.85 & 42.64 & 43.00 & 41.95 & 41.36 & 40.36 & 38.16 & 33.29 & 29.89 & 25.50 \\
& $(5.57)$ & $(3.99)$ & $(3.04)$ & $(2.68)$ & $(2.32)$ & $(2.42)$ & $(1.83)$ & $(1.43)$ & $(1.34)$ & $(1.15)$ \\
EREIT & 36.02 & 30.95 & 26.42 & 28.75 & 29.50 & 23.33 & 21.97 & 10.00 & 3.95 & 1.64 \\
& $(4.14)$ & $(2.53)$ & $(2.03)$ & $(1.60)$ & $(1.29)$ & $(0.90)$ & $(0.48)$ & $(0.12)$ & $(0.00)$ & $(0.00)$ \\
MREIT & 53.48 & 54.33 & 47.99 & 45.69 & 52.88 & 59.36 & 68.13 & 63.88 & 65.93 & 65.31 \\
& $(9.99)$ & $(7.64)$ & $(6.62)$ & $(5.54)$ & $(4.92)$ & $(4.45)$ & $(3.89)$ & $(4.14)$ & $(3.88)$ & $(3.74)$ \\
\hline
\end{tabular}

Notes: The top line in each row shows the probabilities that commercial real estate will have a higher return than residential real estate over the horizon period. The bottom line shows the average relative loss in returns relative to other assets. 
Exhibit 5 reports the bootstrap results. The bootstrap block length is 2 because quarterly returns are used in these tests. Small value stocks again perform better than any other asset class. The results indicate that after taking into account the random nature of the sample, there is a high degree of statistical confidence that small value stocks will provide future returns at least as good as real estate and therefore provide a type of "purchase-early" hedge. The null hypothesis is rejected at the $10 \%$ level for investment horizons eight years and beyond. Equity REITs and Large Value stocks also perform well but their results are not statistically significant at the $10 \%$ level.

Both Exhibits 4 and 5 show similar results to Exhibits 2 and 3. The results are a bit weaker for commercial real estate in Exhibits 4 and 5. It is possible that this is because commercial real estate has higher returns than residential returns. Another possible reason is that the data used for commercial real estate is quarterly as opposed to the monthly data that was used for residential real estate in exhibits 2 and 3. Again the least effective asset class for this type of hedging is T-Bills.

Exhibit 5

A Bootstrap Technique for Commercial Properties

\begin{tabular}{lcccccccccc}
\hline $\begin{array}{c}\text { Horizon } \\
\text { (Year) }\end{array}$ & $\mathbf{1}$ & $\mathbf{2}$ & $\mathbf{3}$ & $\mathbf{4}$ & $\mathbf{5}$ & $\mathbf{6}$ & $\mathbf{7}$ & $\mathbf{8}$ & $\mathbf{9}$ & $\mathbf{1 0}$ \\
\hline Large Value & 35.05 & 30.72 & 29.33 & 26.23 & 23.47 & 22.63 & 20.58 & 18.16 & 17.68 & 16.45 \\
Large Growth & 42.43 & 41.11 & 38.88 & 37.45 & 37.03 & 34.62 & 33.97 & 33.16 & 31.85 & 31.86 \\
Small Value & 30.35 & 25.72 & 20.90 & 17.56 & 15.29 & 12.65 & 11.06 & $9.86^{*}$ & $8.61^{*}$ & $7.47 *$ \\
Small Growth & 49.84 & 49.42 & 50.57 & 49.75 & 50.42 & 50.63 & 50.58 & 49.37 & 50.60 & 50.94 \\
EAFE & 50.45 & 50.53 & 52.21 & 52.21 & 53.49 & 52.74 & 53.05 & 53.42 & 53.42 & 53.56 \\
T-Bills & 82.06 & 86.89 & 91.10 & 94.15 & 95.75 & 97.13 & 97.67 & 98.28 & 98.97 & 99.10 \\
I-T T-Bonds & 55.61 & 57.12 & 58.16 & 59.91 & 59.69 & 61.34 & 61.39 & 63.47 & 63.37 & 63.26 \\
L-T T-Bonds & 51.18 & 49.38 & 49.32 & 48.58 & 48.45 & 48.71 & 49.03 & 48.61 & 47.85 & 47.83 \\
EREIT & 38.21 & 32.60 & 29.65 & 26.56 & 24.67 & 22.51 & 20.59 & 19.09 & 18.41 & 16.18 \\
MREIT & 49.86 & 50.41 & 50.34 & 50.63 & 50.53 & 51.58 & 50.58 & 52.25 & 51.77 & 51.59 \\
\hline
\end{tabular}

Notes: The null hypothesis is that commercial real estate will perform better than the alternative. Low p-values show that there is a high probability of rejecting the null. This means that low p-values indicate that the alternative investment may be a good hedge.

\section{CONCLUSIONS}

If a person or organization is planning to buy real estate in the future but is unable or unwilling to buy it now, how can they best "hedge" this purchase? In what class of asset should they invest their money until they are ready to purchase the real estate? This paper uses Monte Carlo simulation and bootstrap techniques to help answer these questions. We find that the best "purchase early" hedge for both residential and commercial real estate is small value stocks. Small value stocks would be the most likely to provide returns at least as good as real estate and they would be least likely to suffer losses relative to real estate. The effectiveness of the hedge increases the longer the time horizon of the investor. Large value stocks and equity REIT's are also quite good but not as good as small value stocks. Other asset classes are not nearly as effective. The least effective asset class is T-Bills.

Real estate investors now have a rich menu of risk management instruments, such as CME futures and options that are effective in managing short-term real estate risk. This paper focuses on the effectiveness of using traditional asset classes in managing the long-term risks associated with the future purchase of real estate. Our results indicate that when a person or organization decides to wait to purchase real estate, they should invest the money they will ultimately need in small value stocks. ${ }^{3}$ This will allow them the best chance of having enough money to make the purchase and will provide them with the least risk of losing value relative to real estate.

\footnotetext{
${ }^{3}$ We acknowledge that this study focuses at the national market level. The study does not employ submarket data, such as industry stock return data and local housing return data. Given that industry and local real estate market have implications on stock and real estate return, our results should be deemed parsimonious.
} 


\section{AUTHOR INFORMATION}

Allen Atkins is a Professor of finance at Northern Arizona University. He received a BA in Economics from Dartmouth College and Ph.D. in Finance from the University of Texas. He has won numerous teaching awards and has published widely in the area of finance including articles in the Journal of Finance, the Journal of Financial and Quantitative Analysis, the Journal of Financial Research and Organizational Behavior and Human Decision Processes. E-mail: allen.atkins@nau.edu. Corresponding author.

Kevin Chiang is an associate professor of real estate/finance. His research interests include real estate investment trusts, real estate investments, sustainable real estate, and portfolio management. He has published more than 30 academic papers, and many of them are published in prestigious real estate and finance journals.

Ming-Long Lee is a professor of Finance at the National Yunlin University of Science and Technology that is located in Douliou, Yunlin, Taiwan. He has published many papers in the fields of Finance, Economics and Real Estate.

\section{REFERENCES}

1. Bawa, V.S., Optimal Rules for Ordering Uncertain Prospects, Journal of Financial Economics, 2, 95-121.

2. Berg, N., A.Y. Gu, and D. Lien, Dynamic Correlation: A Tool for Hedging House Price Risk, Journal of Real Estate Portfolio Management, 2007, 13, 17-28.

3. Cocco, Joao F., Portfolio Choice in the Presence of Housing, The Review of Financial Studies, 2004, 18, 535-567.

4. Chiang, K., and M. Lee, REITs in the Decentralized Investment Industry, Journal of Property Investment \& Finance, 2002, 20, 496-512.

5. Chiang, K., and M. Lee, Spanning Tests on Public and Private Real Estate, Journal of Real Estate Portfolio Management, 2007, 13, 7-15.

6. Efron, B., Bootstrap Method: Another Look at the Jackknife, The Annals of Statistics, 1979, 7, 1-26.

7. Frost, Kenneth A., Hedging Portfolios with Real Assets, Journal of Portfolio Management, 1995, summer, 21, 60-78.

8. Gyourko, Joseph and Donald B. Keim, What Does the Stock Market Tell Us About Real Estate Returns?, Journal of the American Real Estate and Urban Economics Association, 1992, 20, 457-485.

9. Hall, P., J.L. Horowitz, and B.Y. Jing, On Blocking Rules for the Bootstrap with Dependent Data, Biometrica, 1995, 82, 561-574.

10. Jacobius, Arleen, Hedge Funds Getting Real, Pension \& Investments, 2004, 32, 1-35.

11. Kuhle, James L., Portfolio Diversification and Return Benefits - Common Stock vs. Real Estate Investment Trusts (REITs), The Journal of Real Estate Research, 1987, winter, 2, 1-9.

12. Luenberger, David G., Investment Science, Oxford University Press, 1998, p. 282.

13. Myer, Neil F. C. and James R. Webb, Return Properties of Equity REITs, Common Stocks, and Commercial Real Estate: A Comparison, Journal of Real Estate Research, winter 1993, 8, 87-106.

14. Quan, Daniel and Sheridan Titman, Do Real Estate Prices and Stock Prices Move Together? An International Analysis, Real Estate Economics, 1999, Summer, 27, 183-207.

15. Webb, James R. and C. F. Sirmans, Yields for Selected Types of Real Property vs. the Money and Capital Markets, Appraisal Journal, 1982, 50, 228-242.

16. Wilson, Patrick J. and John Okunev, Evidence of Segmentation in Domestic and International Property Markets, Journal of Property Finance, 1996, 7, 78-97. 